\author{
Przemysław Niewiadomski* \\ Bogdan Nogalski**
}

\title{
STRATEGIA DYFERENCJACJI PRODUKTU JAKO DETERMINANTA WZROSTU WARTOŚCI ZAKŁADU WYTWÓRCZEGO
}

\section{WPROWADZENIE}

Jak zauważa grupa wybitnych uczonych, funkcjonujących pod nazwą Strategor $^{1}$, obserwacja rzeczywistych zachowań przedsiębiorstw konkurujących ${ }^{2}$ między sobą w obrębie jednego sektora już od dawna dawała podstawy do podważenia poszczególnych hipotez modelu konkurencji doskonałej ${ }^{3}$. Rozwój teorii konkurencji monopolistycznej ${ }^{4}$ umożliwił dostrzeżenie problemu zróżnicowania

\footnotetext{
* Dr. inż., Zakład Produkcji Części Zamiennych i Maszyn Rolniczych FORTSCHRITT, Politechnika Poznańska, Wydział Inżynierii Zarządzania.

** Prof. dr hab., Uniwersytet Gdański, Wydział Zarządzania, Instytut Organizacji i Zarządzania.

${ }^{1}$ [Za:] Strategor, Zarzqdzanie firmq. Strategie. Struktury. Decyzje. Tożsamość, PWE, Warszawa 1999, s. 96. Strategor to grupa wybitnych uczonych francuskich z Wydziału Strategii i Polityki Przedsiębiorstwa HEC-ISO z Jouy-en-Josas niedaleko Paryża. Nauczają oni zarządzania strategicznego i polityki firmy w wielu renomowanych francuskich i zagranicznych szkołach zarządzania.

${ }^{2} \mathrm{~W}$ naukach o zarządzaniu pojęcie przewagi konkurencyjnej przedsiębiorstwa jest charakterystyczne przede wszystkim dla problematyki zarządzania strategicznego, chociaż wywodzi się z teorii wzrostu firmy i mikroekonomicznej teorii rynków. Wobec powyższego podjęta przez autorów tematyka badań znajduje swoje uzasadnienie i celowość.

${ }^{3} \mathrm{Na}$ rynku doskonale konkurencyjnym cena jest ,,dana przez rynek” - kształtuje się w wyniku działania mechanizmu rynkowego, jako wypadkowa ofert kupujących i sprzedających. Oznacza to, że żaden z podmiotów (zarówno kupujący, jak i sprzedający) nie jest w stanie indywidualną decyzją zmienić ceny. Aby na danym rynku zaistniała konkurencja doskonała, muszą zostać spełnione określone założenia, wśród których należy wymienić te, dotyczące jednorodności produktu. Założenie to stanowi, iż produkty poszczególnych producentów są identyczne, w związku z czym nabywcom jest wszystko jedno od kogo kupią dany produkt. Szerzej: M. Re ko w s ki, Mikroekonomia, Wydawnictwo AKADEMIA, Poznań 2011.

${ }^{4}$ Zakłada, iż produkty wytwarzane przez firmy są zróżnicowane, niejednorodne.
} 
produktu przez rywalizujących ze sobą wytwórców, co znajduje swoje odzwierciedlenie w niniejszym opracowaniu.

Stanowi ono próbę przybliżenia złożonej tematyki dotyczącej strategii dyferencjacji implementowanych przez zakład wytwórczy wyrobów. W oparciu o wiedzę teoretyczną, jak również własne doświadczenia zawodowe, autorzy za zasadne uznali:

- przeprowadzenie kwerendy literatury przedmiotu pozostającej w bezpośredniej relacji z tematem badań,

- zaproponowanie czynników modelu strategii zakładu wytwórczego bazującego na różnorodności produktowej,

- rozważania teoretyczne przenieść na grunt praktyki; ocena dyferencjacji jakościowej danego produktu pod kątem jego wpływu na rentowność przejawiającą się wzrostem wartości badanego zakładu wytwórczego.

Przyjętym celom opracowania odpowiada założenie, o następującym brzmieniu: unikatowość oferty, będąca wynikiem udoskonalenia wartości użytkowej produktu, pozwala na uzyskiwanie wyższej od przeciętnej w sektorze stopy zysku, co w istotny sposób wpływa na wzrost wartości portfela produktowego, a tym samym wzrost wartości zakładu wytwórczego.

Ponadto, jak sugerują autorzy, im większy udział materiału, wykorzystywanego w procesie produkcji danego wyrobu, tym większa możliwość zastosowania przez wytwórcę, strategii różnicowania jakościowego.

Dokonując analizy strategii dyferencjacji, przedstawiając główne uwarunkowania mające na nią wpływ, autorzy zaproponują rekomendacje w tym zakresie. Dla strategów mogą one być podstawą diagnozy i inspiracją do opracowywania wizji dalszej implementacji.

\section{DYFERENCJACJA A WARTOŚĆ PRZEDSIĘBIORSTWA W TEORII EKONOMII}

\subsection{Strategie wyróżniania - słowem wstępu}

Stosowanie strategii dyferencjacji (wyróżnienia) polega na stworzeniu istotnej dla klienta różnicy między produktem oferowanym przez dany podmiot a wszystkimi innymi substytutami sprzedawanymi przez inne organizacje funkcjonujące na rynku. Strategia ta wymaga odpowiedniego uplasowania oferty i ogromnych nakładów na działania promocyjne, których zadaniem jest wykreowanie wizerunku organizacji. Jest to strategia droga, znacznie podwyższająca koszty stałe organizacji, lecz wysoce skuteczna, pomagająca przedsiębiorstwu nie tyko w pozyskaniu klienta, ale również w znacznym stopniu w utrzymaniu jego lojalności. 
Strategia dyferencjacji, nazywana także strategia przywództwa jakościowego, polega na takim zróżnicowaniu produktu, które przesądza o jego wyjątkowości i oryginalności ${ }^{5}$.

Firma stara się zatem wygrywać jakością, poziomem usług, wyglądem, warunkami i prostotą użytkowania czy sposobem dystrybucji wytworzonego produktu, zabezpieczając się tym samym przed:

- konkurentami w sektorze, gdyż wyróżnianie utrudnia nieuczciwą konkurencję, naśladownictwo, benchmarking w przypadku wyboru takich cech wyrobu, które są bardzo trudne do dokonania ,imitacji”,

- klientami, w przypadku, gdy przedsiębiorstwo potrafi rozpoznawać potrzeby klientów, klient ,przywiązuje się" do marki, jakości, gwarancji dobrej obsługi itp.,

- konkurentami z zewnątrz - wysokie koszty wejścia, trudności w naśladownictwie, obrona przed praktykami nieetycznymi.

Firmy różnicujące wyroby są w dużym stopniu zależne od dostawców, gdyż muszą korzystać z odpowiedniej jakości zasileń do wyprodukowania ponadstandardowych wyrobów; siła przetargowa leży w tym wypadku po stronie dostawców.

\subsection{Zarządzanie zorientowane na wartość firmy}

Zarządzanie zorientowane na wartość firmy ${ }^{6}$ określane jest jako formalne i systematyczne podejście do zarządzania przedsiębiorstwami skierowane na osiagnnięcie celu, jakim jest maksymalizacja wartości dla właścicieli w długim okresie, dzięki optymalnemu wykorzystaniu ekonomicznych mechanizmów zarządzania wartością. Zarządzanie zorientowane na wartość nazywane jest niekiedy jako podejście do zarządzania, w przypadku którego ogólne zamierzenia firmy, techniki analityczne i procesy zarządcze skierowane są na to, aby pomóc firmie maksymalizować jej wartość poprzez skoncentrowanie procesów decyzyjnych na kluczowych czynnikach tworzących wartość ${ }^{7}$.

\footnotetext{
${ }^{5}$ Z. Drążek, B. Ni e mc z y now ic z, Zarzadzanie strategiczne przedsiębiorstwem, PWE, Warszawa 2003, s. 64.

${ }^{6}$ Określane jako (Value Based Management - VBM) - zarządzanie zorientowane na wartość lub jako zarządzanie wartością firmy. Zob. C. D. Ittne r, D. F. Larcker, Assessing Empirical research in managerial accounting. A value-based management perspective, ,Journal of Accounting and Economics" 2010, No. 32, s. 349-410.

${ }^{7}$ A. R appaport, Creating shareholder value. A guide for managers and investors, Simon\&Schuster, New York 1996, [za:] K. Krzaki e wi c z, Przestanki $i$ dylematy wykorzystania koncepcji zarzadzania przez wartość, „Organizacja i Kierowanie” 2012, nr 1A(149), KNOIZ PAN, Szkoła Główna Handlowa, Warszawa, s. 59.
} 
Autorstwo koncepcji maksymalizacji wartości przedsiębiorstwa dla akcjonariuszy przypisywane jest A. Rappaportowi. Koncepcja ta opiera się na założeniu, że maksymalizując tę właśnie wartość, a więc sumę korzyści przysługujących inwestorom $\mathrm{z}$ tytułu posiadania udziałów w firmie, maksymalizuje się także korzyści podmiotów z przedsiębiorstwem powiązanych. Można tu odnaleźć odwołanie do idei „niewidzialnej ręki” Adama Smitha, zgodnie z którą realizacja własnych celów, w tym wypadku najbardziej zyskownego zaangażowania kapitału, prowadzi do sytuacji ze społecznego punktu widzenia najkorzystniejszej ${ }^{8}$.

Według A. Jabłońskiego ${ }^{9}$ produkt, usługa oferowana klientowi jest tylko jednym z czynników gwarantujących osiagnięcie przewagi konkurencyjnej na często wrogim rynku dynamicznie spadających marż zysku. Według przywołanego autora, przedsiębiorstwa nie konkurują produktami, usługami, lecz precyzyjnie skonstruowanymi modelami biznesu.

Autorzy niniejszego opracowania, w dalszej jego części, przedstawią model strategii dyferencjacji, który w oparciu o implementacje wysokomarżowych, wyróżniających się wyrobów, zapewni przedsiębiorstwu maksymalizację jego wartości.

Przyjęcie maksymalizacji wartości dla właścicieli jako nadrzędnego celu funkcjonowania przedsiębiorstwa ma określone konsekwencje dla zarządzania przedsiębiorstwem. Potrzebna jest bowiem strategia, która w najlepszy sposób zaspokajała będzie interesy właścicielskie. Zatem wszystkie zasady, procedury i metody zarządzania powinny być podporządkowane tak zdefiniowanemu celowi.

Poszukując nowych źródeł wartości przedsiębiorstwa coraz powszechniej uznaje się rosnącą rolę implementowanego produktu. Na obecnym etapie rozwoju gospodarki kapitalistycznej mamy bowiem sytuację, w której w celu zaspokojenia tych samych potrzeb wytwarzanych jest wiele podobnych produktów czy usług. W takich warunkach twierdzi się, że to właśnie produkt staje się sposobem odróżnienia firmy od konkurencji oraz drogą do zbudowania trwałej przewagi konkurencyjnej i podniesienia wartości firmy. $Z$ tym właśnie wiąże się przedmiot tej pracy, dotyczący wpływu wartości implementowanego produktu na wartość przedsiębiorstwa. Opracowanie jest zatem próbą odpowiedzi na pytanie - czy implementowanie wyróżniających się produktów niszowych, dających ponadprzeciętne marże - ma wpływ na wartość przedsiębiorstwa i jaka jest skala tego wpływu?

${ }^{8}$ T. D u d y c z, Zarządzanie wartościq przedsiębiorstwa, PWE, Warszawa 2005, s. 17-18.

${ }^{9}$ A. J a błoń ski, Badania modeli biznesu kreujacych wartość, [w:] R. Kr u p ski (red.), Metody badań problemów zarzqdzania strategicznego, Wydawnictwo Wałbrzyskiej Szkoły Zarządzania i Przedsiębiorczości, Wałbrzych 2010, s. 293. 


\section{WSPOMAGANIE STRATEGII RÓŻNORODNOŚCI PRODUKTOWEJ - ZAŁOŻENIA MODELOWE}

Przy modelowaniu strategii dyferencjacji, autorzy wskazują na cztery główne elementy (zob. rys. 1) wspomagające jej powodzenie:

- przywództwo kosztowe w zakresie dostaw,

- produkty niszowe ${ }^{10}$ dające ponadprzeciętne marże,

- wzrost ceny adekwatny do podnoszonej jakości wyrobu,

- umiędzynarodowienie produktu.

Poniżej zostanie omówiony pokrótce każdy nich.

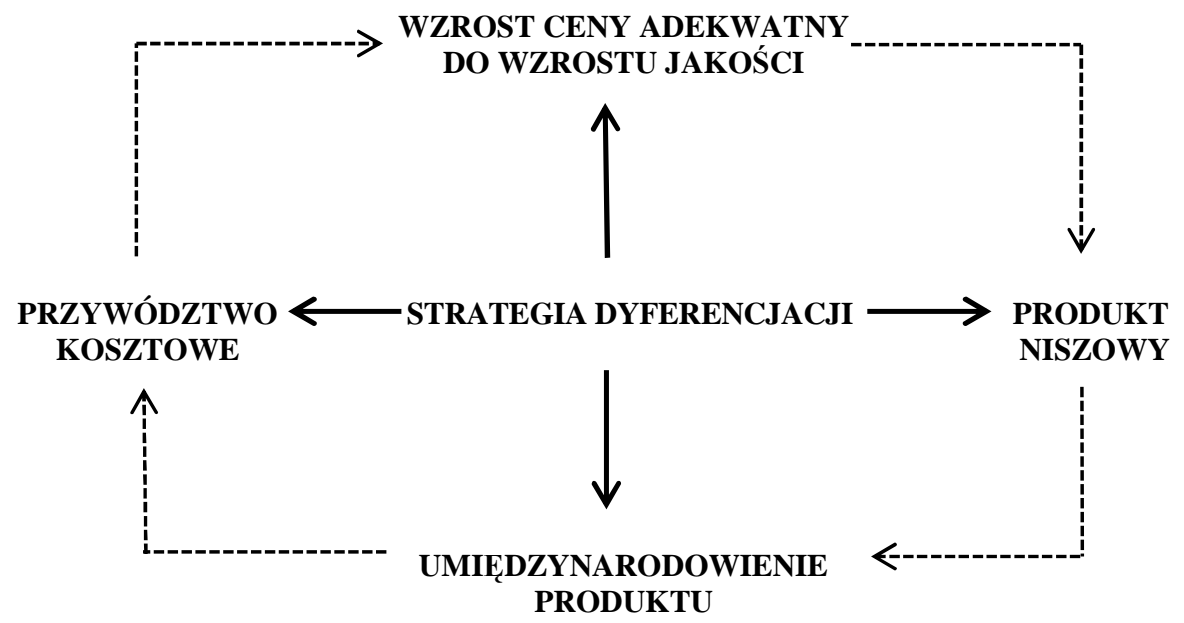

Rys. 1. Czynniki wspomagające strategię dyferencjacji - ujęcie modelowe

Źródło: opracowanie własne.

Zmiany zachodzące $\mathrm{w}$ zewnętrznych uwarunkowaniach funkcjonowania przedsiębiorstw zmuszają je do poszukiwania względnie trwałych warunków dla wzrostu wartości i podejmowania w tym celu działań strategicznych modelowo traktowanych jako strategie internacjonalizacji ${ }^{11}$.

${ }^{10}$ Według M. Moszkowicza, niszą rynkową nazywa się pewną niewielką grupę odbiorców, oczekujących na zaspokojenie wyraźnie sprecyzowanych potrzeb. Zapotrzebowanie to dotyczy zarówno nabycia produktów, jak i usług. Czynnikiem wpływającym na decyzje zakupowe klientów może być zarówno cena, jak i jakość danego produktu czy też usługi, [za:] M. Mos zkow i c z, Zarzqdzanie strategiczne. Systemowe koncepcje biznesu, PWE, Warszawa 2005, s. 158.

${ }^{11}$ E. Urbanow ska-Sojkin, Praktyka zarzqdzania strategicznego. Studia polskich przypadków, PWE, Warszawa 2008, s. 17. 
Według autorów opracowania może ona prowadzić do wzrostu konkurencyjności przedsiębiorstw poprzez:

- obniżkę kosztów ${ }^{12}$ - wynika ona z korzyści skali, niższych kosztów wytwarzania, ograniczania liczby produktów;

- poprawę jakości produktów i efektywności programów, co jest efektem skoncentrowania się przedsiębiorstwa (zasobów i umiejętności) na produkcji mniejszej ilości produktów (modeli);

- wzmocnienie preferencji klientów na skutek dostępności produktu na wszystkich rynkach oraz globalnej znajomości marki.

$\mathrm{Z}$ punktu widzenia omawianej $\mathrm{w}$ niniejszym opracowaniu strategii przedsiębiorstw, autorzy zakładają, że umiędzynarodowienie produktów umożliwia sekwencyjne wchodzenie na niszowe rynki zagraniczne z tym samym, wystandaryzowanym wyrobem, co pozytywnie może wpływać na podnoszenie marży (zysku) uzyskiwanej ze sprzedaży danego, unikatowego produktu. Według autorów opracowania, racjonalnie myślący producent, powinien upatrywać swoich możliwości rozwojowych w kontekście rynków wysoko rozwiniętych czyli tzw. krajów wiodących ${ }^{13}$, gdzie odchodzi się od walki cenowej ${ }^{14}$. Wobec powyższego należy szukać rynków zbytu, tam gdzie głównym kryterium, źródłem przewag konkurencyjnych będzie unikalny, wyróżniający się produkt a nie wyniszczające firmy, walki cenowe.

Stąd wzrastająca w ostatnich latach rola i znaczenie rynków niszowych, gdzie ma miejsce zwiększone zapotrzebowanie na produkty wysoko wyspecjalizowane, co z kolei ogranicza zakusy producentów na obniżanie cen oferowanych wyrobów.

W gospodarce światowej, w tym także na rynku polskim, coraz częściej obserwuje się zjawisko kierowania oferty biznesowej do określonej grupy wyznaczającej specyficzne segmenty rynku - nisze rynkowe, które obsługiwać musi dostosowana do nich, zindywidualizowana oferta przedsiębiorstw.

${ }^{12}$ Globalizacja działalności pozwala podmiotom gospodarczym wykorzystywać globalne korzyści skali, zasięgu, doświadczenia i synergii, co stanowić może o uzyskaniu przewagi konkurencyjnej

${ }^{13}$ Kraje wiodące - to kraje o wysokiej innowacyjności produktowej lub wdrażające innowacyjne procesy produkcji. Charakteryzuje je masowość pojawiających się innowacji oraz obecność na ich rynkach głównych konkurentów globalnych. Dążenie firm do wzrostu powoduje, że firmy te za priorytet stawiają sobie uczestnictwo w rynkach krajów wiodących. Pewną korzyścią z obecności na rynkach krajów wiodących jest postrzeganie przez klientów wyrobów tych firm, jako produktów o wysokiej jakości

${ }^{14}$ Jak wynika z obserwacji i praktycznych doświadczeń autorów, niestety polskie przedsiębiorstwa taką wyniszczającą strategię stosują nagminnie, nie biorąc pod uwagę, iż $w$ ten sposób ograniczają własne możliwości rozwojowe. Autorzy sugerują wykorzystywanie innych narzędzi konkurowania i stopniowe odchodzenie od niepotrzebnego zaniżania ceny. W perspektywie wzrostu wartości przedsiębiorstwa takie działania są nieuzasadnione, żeby nie powiedzieć nieracjonalne. 
Tworzenie nisz rynkowych związane jest często z dążeniem do zapewnienia wysokiej rentowności działania przedsiębiorstwa, również poprzez uzyskiwanie ponadprzeciętnej marży ze sprzedaży danego dobra. Stąd sugeruje się poszukiwanie niszy rynkowej, zwłaszcza w kontekście rynków zagranicznych.

Analiza konkurencyjności przedsiębiorstw prowadzi do wyodrębnienia konkurencyjności odnoszącej się do określonych obszarów oraz czynników towarzyszących $\mathrm{w}$ rezultacie konkurencyjności przedsiębiorstwa. Z. Pierścionek wyróżnia takie koncepcje, które koncentrują się na czynnikach realnych. Zajmują się wpływem technologii, specjalizacji, dywersyfikacji, skali produkcji, doświadczenia czy zasobów surowcowych, na konkurencyjność przedsiębiorstwa $^{15}$.

Procesy związane z szeroko rozumianym zaopatrzeniem to tylko jeden z istotnych aspektów zarządzania firmą, który może decydować o sukcesie bądź porażce przedsiębiorstwa na rynku ${ }^{16}$. Logistyka zaopatrzenia wykorzystuje istniejące możliwości zaopatrzenia, koordynując przepływ towarów i informacji w celu zapewnienia przedsiębiorstwu materiałów używanych do produkcji lub do sfery handlu. Działania zaopatrzenia wykraczają niekiedy swoim zasięgiem poza przedsiębiorstwo, poza granice kraju - podejmowane są wewnątrz, ale wpływają na zewnętrzne przygotowanie potrzeb materiałowych poprzez odpowiednie systemy ${ }^{17}$.

Stąd też w zakresie działania logistyki zaopatrzenia jest nie tylko zakup materiałów czy elementów do produkcji, ale także ich transport i magazynowanie przy minimalizacji kosztów. Logistyka zaopatrzenia jest więc systemem celowym, który działa w szerokim zakresie, od rynku dostawców do rynków zbytu, i bazuje na zintegrowanej koncepcji pozyskiwania potrzebnych materiałów we właściwej ilości i asortymencie, o właściwej jakości i cenie, we właściwym miejscu i czasie.

Koncepcja strategii forsowanej przez autorów w niniejszym opracowaniu, zdaje się potwierdzać, iż konkurencyjność firmy wynika m. in. z przywództwa kosztowego lub/i wyższej jakości wytwarzanych dóbr ${ }^{18}$.

${ }^{15}$ Artykuł: Z. Pi erści o n e k, Ewolucja koncepcji konkurencyjności przedsiębiorstwa, Katedra Zarządzania Strategicznego, Szkoła Główna Handlowa. www.centrumwiedzy.edu.pl.

${ }^{16} \mathrm{~J}$. Łuczak, System zarzqdzania jakościa dostawców w branży motoryzacyjnej - ocena istotności wymagań, Wydawnictwo Akademii Ekonomicznej w Poznaniu, Poznań 2008, s. 36.

${ }_{17}$ J. D y c zkowska, Logistyka zaopatrzenia i produkcji - wptyw na logistyke dystrybucji, Zeszyty Naukowe Politechniki Warszawskiej nr 84, Warszawa 2012, s. 20.

${ }^{18} \mathrm{~W}$ tym miejscu autorzy nadmieniają, że wzrost jakości powinien odzwierciedlać się w cenie wyrobu finalnego. Każdorazowy wzrost jakości danego wyrobu powoduje wzrost kosztów jego wytworzenia, co musi być uwzględnione przez producenta i odzwierciedlone w cenie. Nie sposób jest bowiem otrzymać najwyższą jakość po najniższych kosztach, o czym zdają się zapominać konsumenci. Wobec powyższego należy zdawać sobie sprawę, że kupując tanio, nie można spodziewać się produktu unikalnego pod względem jego doskonałości. 
Wskazana przez autorów opracowania strategia przywództwa kosztowego wymaga, by firma była liderem w zakresie zaopatrzenia po niskich kosztach ${ }^{19}$. Jeżeli przedsiębiorstwo zdobędzie i utrzyma przywództwo kosztowe na wejściu, to będzie miało zyski wyższe od przeciętnych w gałęzi, pod warunkiem oczywiście, że będzie oferowało ceny na poziomie akceptowalnym przez dany rynek.

\section{OFERTA STANDARDOWA A OFERTA WYRÓŻNIAJĄCA SIĘ W PRAKTYCE ZAKŁADÓW WYTWÓRCZYCH}

\subsection{Przedmiot i podmiot badań}

Badania, o których mowa w dalszej części opracowania, prowadzono w Zakładzie Produkcji Części Zamiennych i Maszyn Rolniczych. Główną formą działalności badanego przedsiębiorstwa jest proces produkcji podzespołów oraz części zamiennych ${ }^{20}$ wykorzystywanych $\mathrm{w}$ procesie produkcji gotowych maszyn.

Oferta zakładu to obszerny pakiet systemów i rozwiązań dla nowoczesnego rolnictwa, który został zaprojektowany z myślą o najbardziej wymagających klientach, poszukujących najwyższej jakości części maszyn charakteryzujących się niezawodnością pracy ${ }^{21}$.

W celu weryfikacji hipotezy, autorzy za zasadne uznali zasymulowanie dwóch wariantów produktu (ściana boczna przyczepy rolniczej), a mianowicie produktu standardowego i produktu udoskonalonego, stanowiącego podstawę strategii dyferencjacji.

Odniesienie kosztów wytworzenia produktu, według danego wariantu, do jego ceny rynkowej pozwoli autorom zobrazować korzyści jakie osiąga wytwórca, w wyniku zastosowanej strategii.

W prowadzonych badaniach autorzy zamierzają wykazać, iż produkcja możliwie dużej ilości niestandardowych (wyróżniających się na tle konkurencji) części i podzespołów, w ramach własnego przedsiębiorstwa, jest najlepszą strategią jaką producent może realizować z punktu widzenia kreowania wartości danego zakładu wytwórczego.

${ }^{19}$ Jako, że owa strategia ma duży wpływ na wyniki ekonomiczne przedsiębiorstwa musi uwzględniać działania takie jak: precyzyjna prognoza potrzeb, dokładne badanie rynku, zbudowanie długookresowych powiązań z dostawcami, kontrola zapasów i kontrola dostawców. Zagadnienia te są przedmiotem odrębnych opracowań autorów, stąd w niniejszej publikacji traktowane są kontekstowo.

${ }^{20}$ Asortyment części zamiennych obejmuje zamienniki do kombajnów zbożowych, sieczkarni, kosiarek, rozrzutników obornika, pługów, pras i przyczep rolniczych.

${ }^{21}$ Informacje uzyskane podczas wywiadu bezpośredniego przeprowadzonego $\mathrm{z}$ właścicielem firmy w ramach realizowanych, przez autorów niniejszego opracowania, badań. 


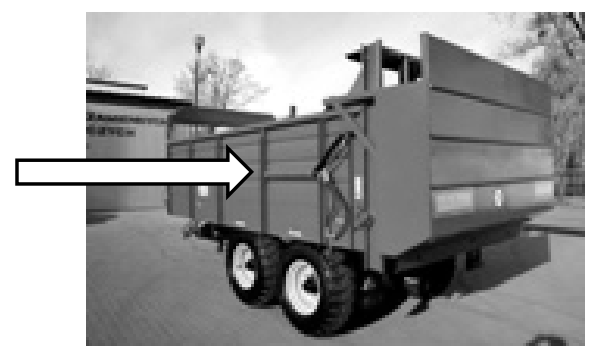

Rys. 2. Rozrzutnik obornika ZPCZ-T-088

\section{Źródło: zpcz.pl}

Stosowanie strategii różnicowania, o której mowa w dalszej części pracy dotyczy jakości produktu ${ }^{22}$, rozumianej jako stopień spełnienia przez niego oczekiwań i wymagań klientów ${ }^{23}$.

Istotą strategii wyróżnienia poprzez jakość jest przekonanie klienta, że oferta danej firmy ma takie cechy, które w zasadniczy sposób zwiększają jej wartość postrzeganą przez klienta w porównaniu ze wszystkimi innymi dostępnymi na rynku

\subsection{Ekonomiczna efektywność dyferencjacji w praktyce zakładów wytwórczych}

Jak zauważa K. Obłój ${ }^{24}$ jednym z pionierów poszukiwania przewagi w specyfice jakości oferty i zwiększania rentowności drogą podwyższania cen był General Motors na początku XX w. Według tego autora ostatecznym celem budowy strategii zróżnicowania jest stworzenie marki firmy, marki produktów i związanie z nimi klienta, co według autorów niniejszego opracowania znajduje swój wyraz w wyższych od konkurentów zyskach uzyskiwanych z implementacji danego dobra.

${ }^{22} \mathrm{~K}$. Obłój, analizując cztery bazowe przewagi konkurencyjne, wymienia relacje pomiędzy ceną a jakością jako jedną z nich. Wzrost jakości funkcji wyrobu jest źródłem budowy przewagi konkurencyjnej, [za:] P. Jedynak, Ocena znormalizowanych Systemów zarzqdzania jakościa, Wydawnictwo Uniwersytetu Jagiellońskiego, Kraków 2007, s. 22. Rolę jakości w budowaniu przewagi konkurencyjnej podkreśla E. Skawińska. W stworzonym przez autorkę dynamicznym modelu strumieni budowy konkurencyjności przedsiębiorstwa, jakość wyrobu zajmuje miejsce instrumentu konkurowania, zaś system zarządzania jakością znajduje się wśród komponentów potencjału konkurencyjności i umiejętności przedsiębiorstwa. Zob.: E. S kaw ińska, Konkurencyjność przedsiębiorstw - nowe podejście, PWN, Warszawa-Poznań 2002, s. 83.

${ }^{23}$ P. Jedynak zauważa, że niezależnie od zmian koncepcji zarządzania, jakość zachowała status bardzo istotnego, jeśli nie kluczowego, czynnika konkurencyjności przedsiębiorstw, [za:] P. Jed ynak, op. cit., s. 7.

${ }^{24}$ K. O błój, Pasja i dyscyplina strategii. Jak z marzeń i decyzji zbudować sukces firmy, Poltext, Warszawa 2010, s. 140. 
Są sektory w Polsce, w których trwa mordercza walka konkurencyjna. Przekładem jest sektor producentów części do maszyn rolniczych, o którym mowa w niniejszym opracowaniu. W ramach tego sektora producenci walczą zarówno o wzrost, jak i podział rynku. Niestety najczęściej stosowaną strategią jest tu strategia niskich cen, co z kolei przejawia się niską rentownością sektora oraz implementowaniem produktu niskiej jakości.

Odmienną filozofię konkurowania, opartą na opracowanym w poprzedniej części modelu, reprezentują autorzy niniejszego opracowania. Ograniczanie kosztów w zakresie dostaw, implementowanie niszowych produktów wysokomarżowych, wzrost jakości kreujący możliwość podnoszenia cen poprzez wejście na rynki światowe, wszystko to ma zapewnić producentowi wzrost wartości firmy.

W dalszej części opracowania przedstawiono wyniki prowadzonych badań, które zdają się potwierdzać zasadność stosowania strategii według przyjętych w modelu, wytycznych.

Tabela 1

Koszty produkcji ściany bocznej przyczepy rolniczej - oferta standardowa

\begin{tabular}{|c|c|c|c|c|}
\hline \multirow{2}{*}{$\begin{array}{l}\text { Koszty surowca netto PLN/szt. } \\
\text { W tym: }\end{array}$} & \multicolumn{4}{|r|}{213,05} \\
\hline & Waga/szt. & Ilość/szt. & $\begin{array}{l}\text { Cena netto su- } \\
\text { rowca PLN/kg }\end{array}$ & $\begin{array}{l}\text { Suma netto } \\
\text { PLN/szt. }\end{array}$ \\
\hline Blacha $1915 \times 930 x 1$ & 14,25 & 1 & 2,24 & 31,92 \\
\hline Blacha 1425x930x1 & 10,60 & 1 & 2,24 & 23,74 \\
\hline Blacha $1075 \times 930 \times 1$ & 8,00 & 1 & 2,24 & 17,92 \\
\hline Profil 60x60x3 - (L-4600) & 24,70 & 1 & 2,50 & 61,75 \\
\hline Blacha 60x60x2 & 0,06 & 2 & 2,30 & 0,28 \\
\hline Blacha $1160 \times 175 \times 2$ & 3,25 & 5 & 2,30 & 37,38 \\
\hline Blacha 1160x265x2 & 4,92 & 1 & 2,30 & 11,32 \\
\hline Blacha $450 \times 38 \times 2$ & 0,27 & 2 & 2,30 & 1,24 \\
\hline Rura 22x3 - (L-100) & - & 5 & 25,00 & 12,50 \\
\hline Rura 28x3 - ( L-200) & - & 3 & 25,00 & 15,00 \\
\hline Koszty pracy PLN/szt. & & & & 59,00 \\
\hline \multirow{2}{*}{ W tym: } & Cięcie & Spawanie & Wyginanie & Malowanie \\
\hline & 25,00 & 25,00 & 6,00 & 3,00 \\
\hline Pozostałe koszty PLN/szt. & & & & 59,00 \\
\hline \multicolumn{3}{|l|}{ Koszty produkcji PLN/szt. } & & 331,05 \\
\hline \multicolumn{3}{|l|}{ Cena sprzedaży PLN/szt. } & & 500,00 \\
\hline \multicolumn{3}{|l|}{ Zysk/marża PLN/szt. } & & 168,95 \\
\hline
\end{tabular}

Źródło: opracowanie własne na podstawie badań. 
W tab. 1 przedstawiono koszty produkcji ściany bocznej przyczepy rolniczej, które zostały opracowane w kontekście standardowych działań firmy. Niestety w ramach oszczędności producent znacznie „odchudził” wyrób finalny, stosując $\mathrm{w}$ procesie produkcji $\mathrm{m}$. in. blachę o grubości $1 \mathrm{~mm}$. $\mathrm{Z}$ racji funkcji, jaką produkt ma realizować, jest to działanie znacznie obniżające wartość użytkową produktu. Koszty wytworzenia ściany bocznej przyczepy rolniczej, wykonanej według takiej specyfikacji, oscylują na poziomie $331,05 \mathrm{PLN} / \mathrm{szt}^{25}$ Cenę sprzedaży rynek krajowy kształtuje na poziomie 500,00 PLN/szt. Wobec powyższego, zysk jaki osiagga producent ze sprzedaży jednej sztuki wyrobu wynosi 168,95 PLN.

W dalszej części pracy przedstawiono implementację ściany bocznej przyczepy rolniczej według kryteriów przyjętych przez autorów, w opracowanym przez nich modelu (tab. 2).

W ramach negocjacji z dostawcą materiałów wykorzystywanych w procesie produkcji ściany bocznej, uzyskano istotne oszczędności. Szczegółowa analiza dostawy wykazała, że surowiec do produkcji zostanie zakupiony w następujących cenach: blacha od 2,04 do 2,10 PLN/kg, profil - 2,24 PLN/kg, natomiast rura - 18,00 PLN za metr bieżący.

W ramach wyróżnienia produktu, wpływając na jego wartość użytkową, producent zastosował $\mathrm{w}$ procesie produkcji blachę o grubości $2 \mathrm{~mm}^{26}$. Oczywiście koszty wytworzenia wyrobu lepszej jakości będą wyższe, jednakże poprzez jakościowe wyróżnienie produktu, producent otwiera sobie możliwość wejścia na rynki zagraniczne, w tym rynek niemiecki, gdzie cena sprzedaży wyrobu będzie znacznie wyższa niż w Polsce. Powyższe przedstawiono w tab. 2.

Koszty wytworzenia ściany bocznej przyczepy rolniczej, wykonanej według wyższych standardów jakościowych, oscylują na poziomie 408,57 PLN/szt. ${ }^{27}$ Cena sprzedaży na rynek niemiecki kształtuje się na poziomie 1200,00 PLN/ szt. Wobec powyższego, zysk jaki osiaga producent ze sprzedaży jednej sztuki wyrobu wynosi 791,43 PLN.

${ }^{25}$ W tym koszty surowca wynoszą 201,05 PLN, koszty pracy 59,00 PLN. Pozostałe koszty (stanowiące 100\% kosztów pracy) kształtują się na poziomie 59,00 PLN.

${ }^{26}$ Takie działanie powoduje wzrost kosztów wytworzenia wyrobu. Biorąc pod uwagę sposób kalkulacji wyrobów wytwarzanych z blachy (gdzie $1 \mathrm{~m}^{2}$ blachy o grubości $1 \mathrm{~mm}$ waży $8 \mathrm{~kg}$ ), koszt wytworzenia wyrobu wzrasta o $100 \%\left(1 \mathrm{~m}^{2}\right.$ blachy o grubości $2 \mathrm{~mm}$ waży $\left.16 \mathrm{~kg}\right)$. Stąd autorzy zakładają konieczność obniżania kosztów poprzez polepszanie ceny zakupu surowca. Niestety większość przedsiębiorców nie zdaje sobie sprawy jak istotne jest odpowiednie zarządzanie procesami zakupowymi, jakie oszczędności można uzyskać odpowiednio dobierając dostawców. Dlaczego tak ważną rolę przypisuje się menedżerom sprzedaży, zapominając o menedżerach dokonujących zakupu? Tą kwestię autorzy zamierzają podjąć w kolejnych publikacjach, przyglądając się procesom zakupowym realizowanym w badanych przedsiębiorstwach.

${ }^{27}$ W tym koszty surowca wynoszą 300,57 PLN, koszty pracy 59,00 PLN. Pozostałe koszty (stanowiące $83 \%$ kosztów pracy) kształtują się na poziomie 49,00. 
Koszty produkcji ściany bocznej przyczepy rolniczej - oferta wyróżniająca się w kontekście autorskich założeń

\begin{tabular}{|c|c|c|c|c|}
\hline Koszty surowca netto PLN/szt. & & & & 300,57 \\
\hline W tym: & Waga/szt. & Ilość/szt. & $\begin{array}{l}\text { Cena netto su- } \\
\text { rowca PLN/kg }\end{array}$ & $\begin{array}{l}\text { Suma netto } \\
\text { PLN/szt. }\end{array}$ \\
\hline Blacha $1915 \times 930 \times 2$ & 28,50 & 1 & 2,04 & 58,14 \\
\hline Blacha 1425x930x2 & 21,20 & 1 & 2,04 & 43,25 \\
\hline Blacha $1075 \times 930 \times 2$ & 16,00 & 1 & 2,04 & 32,64 \\
\hline Profil 60x60x3 - (L-4600) & 24,70 & 1 & 2,24 & 55,33 \\
\hline Blacha 60x60x4 & 0,12 & 2 & 2,10 & 0,25 \\
\hline Blacha $1160 \times 175 \times 4$ & 6,50 & 5 & 2,10 & 68,25 \\
\hline Blacha 1160x2,65x4 & 9,84 & 1 & 2,10 & 20,66 \\
\hline Blacha 450x38x4 & 0,55 & 2 & 2,05 & 2,25 \\
\hline Rura 22x3 - (L-100) & - & 5 & 18,00 & 9,00 \\
\hline Rura 28x3 - ( L-200) & - & 3 & 18,00 & 10,80 \\
\hline Koszty pracy PLN/szt. & \multicolumn{4}{|c|}{59,00} \\
\hline \multirow{2}{*}{ W tym: } & Cięcie & Spawanie & Wyginanie & Malowanie \\
\hline & 25,00 & 25,00 & 6,00 & 3,00 \\
\hline Pozostałe koszty PLN/szt. & & & & $49,00^{28}$ \\
\hline \multicolumn{3}{|l|}{ Koszty produkcji PLN/szt. } & & 408,57 \\
\hline \multicolumn{3}{|l|}{ Cena sprzedaży PLN/szt. } & & $1200,00^{29}$ \\
\hline \multicolumn{3}{|l|}{ Zysk/marża PLN/szt. } & & 791,43 \\
\hline
\end{tabular}

Źródło: jak do tab. 1.

Uzyskanie tak wysokiej marży było możliwe dzięki zastosowaniu strategii dyferencjacji (wzrost jakości wyrobu, który warunkuje możliwość implementacji wyrobu na rynkach, gdzie jakość stanowi istotny element gry rynkowej). Wzrost jakości wyrobu o 100\% był możliwy dzięki zastosowaniu wyższej jakości surowca, mierzonego według parametru jego grubości. Jednakże dzięki zastosowaniu strategii obniżania kosztów przy zakupie surowca, poprzez odpowiedni dobór dostawcy, koszty produkcji nie wzrosły wprost proporcjonalnie do

${ }^{28} \mathrm{~W}$ ramach negocjacji cenowych, prowadzonych w ramach badań, producent otrzymał dodatkowy opust w postaci przeniesienia kosztów transportu na dostawcę. Pozwoliło to na obniżenie poziomu pozostałych kosztów o 10,00 PLN.

${ }^{29}$ Cena sprzedaży wyrobu, którą jest wstanie zaakceptować rynek niemiecki wynosi 288,50 euro. Dane pochodzą z analiz prowadzonych przez firmę Granit - spółkę córkę niemieckiej firmy FRICKE GMBH. Średni kurs euro na dzień 15.03.2013 wynosi 4,1595 PLN. Wobec powyższego, po przeliczeniu według kursu, rynek ustala cenę na poziomie 1200,00 PLN za jedną sztukę ściany bocznej przyczepy. Zob.: Tabela kursów nr 053/A/NBP/2013 z dnia 15.03.2013. 
wzrostu jakości. W kontekście powyższego, autorzy potwierdzili, iż wysokiej jakości produkt niszowy implementowany na rynkach zagranicznych (strategia internacjonalizacji) daje możliwość wzrostu wartości zakładu wytwórczego, dzięki istotnie wysokiej marży, która w omawianym przypadku wynosi 791,43 PLN/szt.

\section{WNIOSKI}

W niniejszym opracowaniu potwierdzono, że strategia wyróżniania, odpowiednio wspomagana, determinuje wzrost wartości zakładu wytwórczego. Wobec powyższego postawiona przez autorów teza znalazła potwierdzenie w całej swojej rozciagłości.

Przeprowadzone przez autorów artykułu badania, predysponują ich do zaprezentowania istotnych wniosków:

- prowadząc działalność implementacyjną, zakład wytwórczy ponosi koszty, których wielkość porównana z przychodami, decyduje o osiągniętym wyniku finansowym;

- unikatowość oferty, będąca wynikiem udoskonalenia wartości użytkowej produktu, pozwala na uzyskiwanie wyższej od przeciętnej w sektorze stopy zysku, co w istotny sposób wpływa na wzrost wartości portfela produktowego, a tym samym zakładu wytwórczego;

- im większy udział materiału, wykorzystywanego w procesie produkcji danego wyrobu, tym większa możliwość zastosowania przez wytwórcę, strategii różnicowania jakościowego, i tym większe znaczenie ma dobór dostawcy $\mathrm{w}$ procesie nabywania surowców wykorzystywanych w procesie jego produkcji - przywództwo kosztowe w zakresie dostaw;

- zasadne jest implementowanie produktów niszowych, gdyż tylko takie dają ponadprzeciętne marże, przekładające się na wzrost wartości firmy;

- umiędzynarodowienie produktu, pozwalające na osiąganie wyższej marży, jest możliwe dzięki podnoszeniu jakości wyrobu do poziomu akceptowalnego na rynku, na którym producent chce lokować dany wyrób.

W ramach jednej publikacji nie można było pomieścić nawet najbardziej skondensowanego przeglądu wszystkich pojęć, koncepcji i rozwiązań dotyczących strategii dyferencjacji. Dokonując wyboru omawianych zagadnień, starano się zachować pewną spójność logiczną prowadzonych rozważań, pokazując równocześnie podstawowe cechy i trudności związane z ową strategią. 


\section{BIBLIOGRAFIA}

Drążek Z., Niemczynowicz B., Zarzqdzanie strategiczne przedsiębiorstwem, PWE, Warszawa 2003.

D u d y c z T., Zarzadzanie wartościa przedsiębiorstwa, PWE, Warszawa 2005.

D y c z kow s k a J., Logistyka zaopatrzenia i produkcji - wptyw na logistykę dystrybucji, Zeszyty Naukowe Politechniki Warszawskiej nr 84, Warszawa 2012.

It t n e r C. D., La r cker D. F., Assessing Empirical research in managerial accounting . A value-based management perspective, ,Journal of Accounting and Economics” 2010, No. 32.

Jabłońs ki A., Badania modeli biznesu kreujących wartość, [w:] R. Krupski (red.), Metody badań problemów zarzqdzania strategicznego, Wydawnictwo Wałbrzyskiej Szkoły Zarządzania i Przedsiębiorczości, Wałbrzych 2010.

J e d y nak P., Ocena znormalizowanych Systemów zarzadzania jakościa, Wydawnictwo Uniwersytetu Jagiellońskiego, Kraków 2007.

Krzakiewicz K., Przestanki i dylematy wykorzystania koncepcji zarzqdzania przez wartość, „Organizacja i Kierowanie” 2012, nr 1A (149), KNOIZ PAN, Szkoła Główna Handlowa, Warszawa.

Łu c zak J., System zarzadzania jakościa dostawców w branży motoryzacyjnej-ocena istotności wymagań, Wydawnictwo Akademii Ekonomicznej w Poznaniu, Poznań 2008.

Moszkowicz M., Zarzadzanie strategiczne. Systemowe koncepcje biznesu, PWE, Warszawa 2005.

Obłój K., Pasja i dyscyplina strategii. Jak z marzeń i decyzji zbudować sukces firmy, Poltext, Warszawa 2010.

Pi erści on ek Z., Ewolucja koncepcji konkurencyjności przedsiębiorstwa, Katedra Zarządzania Strategicznego, Szkoła Główna Handlowa. www.centrumwiedzy.edu.pl

$\mathrm{R}$ a p p a p ort A., Creating shareholder value. A guide for managers and investors, Simon\&Schuster, New York 1996.

R e kow s k i M., Mikroekonomia, Wydawnictwo AKADEMIA, Poznań 2011.

S k a wińs k a E., Konkurencyjność przedsiębiorstw - nowe podejście, PWN, Warszawa-Poznań 2002.

S tr a te g o r, Zarzqdzanie firmq. Strategie. Struktury. Decyzje. Tożsamość, PWE, Warszawa 1999. Urbanowska-Sojkin E. (red.), Praktyka zarzadzania strategicznego. Studia polskich przypadków, PWE, Warszawa 2008.

Przemystaw Niewiadomski, Bogdan Nogalski

\section{PRODUCT DIFFERENTIATION STRATEGY AS A GROWTH DETERMINANT OF A MANUFACTURING PLANT}

This study is an attempt to approximate the complex issues relating to the differentiation strategy of products implemented by a manufacturing plant. Based on theoretical knowledge as well as their own professional experience, the authors found it appropriate to conduct the subject literature queries, remaining in direct relation to the topic of the research. In the further part of the paper it was considered appropriate to develop a manufacturing plant strategy model based on product diversity. The authors intend to move the conducted theoretical considerations to the field of practice, assessment of quality of the product differentiation in terms of its impact on the profitability manifested by an increase in the value of the studied manufacturing plant.

Key words: differentiation strategy, product quality, manufacturing plant, the value of the company. 